\title{
Performance Study of Platinum Nanoparticles Supported onto MWCNT in a Formic Acid Microfluidic Fuel Cell System
}

\author{
Jiwei Ma, Aldo S. Gago, ${ }^{a}$ and Nicolas Alonso-Vante, ${ }^{*, z}$ \\ IC2MP, UMR-CNRS 7285, University of Poitiers, 86022 Poitiers, France
}

\begin{abstract}
The Pt/MWCNT and Pt/C catalysts were synthesized using the carbonyl chemical route. The catalysts were physically and electrochemically characterized. An enhanced stability under potential cycling is obtained with Pt/MWCNT as compared to that of $\mathrm{Pt} / \mathrm{C}$. The evaluation of the electrochemical stability in a microfluidic fuel cell system was in good agreement with the results obtained in half-cell tests. Increasing the applied current from 10 to $40 \mathrm{~mA}$, the Pt/MWCNT cathode potential in the fuel cell system depolarized $67 \%$ less than Pt/C. The performance of the fuel cell with Pt/MWCNT cathode was 2 times higher compared to Pt/C, under a constant current of $40 \mathrm{~mA}$ for $1000 \mathrm{~s}$. The results from half-cell and fuel cell measurements showed that Pt/MWCNT is a more suitable cathode for microfluidic fuel cell than Pt/C due to the properties of the carbonaceous substrate. The Pt/MWCNT cathode was subsequently used in a formic acid microfluidic fuel cell to study several system parameters including formic acid concentration, cell orientation and bubble effect.
\end{abstract}

(C) 2013 The Electrochemical Society. [DOI: 10.1149/2.101308jes] All rights reserved.

Manuscript submitted February 28, 2013; revised manuscript received May 22, 2013. Published May 28, 2013.

Micro direct methanol fuel cells ( $\mu$ DMFC) are promising power sources for low-power applications in mobile communications, computers and electronic devices. ${ }^{1,2}$ The $\mu$ DMFC have attracted considerable interest from the academic and industrial sector to be used as portable energy devices. One alternative fuel to methanol (4.69 $\mathrm{kWh} / \mathrm{L})$ is formic acid $(2.08 \mathrm{kWh} / \mathrm{L}) .{ }^{3-5}$ Formic acid can be electrochemically oxidized: ${ }^{6}$

$$
\mathrm{HCOOH} \rightarrow \mathrm{CO}_{2}+2 \mathrm{H}^{+}+2 \mathrm{e}^{-} \quad \mathrm{E}^{\circ}=-0.25 \mathrm{~V} / \mathrm{SHE}
$$

Micro direct formic acid fuel cells ( $\mu$ DFAFC) can therefore operate at higher working voltage than $\mu$ DMFCs. ${ }^{3-5}$ Another advantage in using formic acid is its high oxidation kinetics on palladium electrodes. ${ }^{7-9}$ Nonetheless, the commercialization of fuel cells that uses either methanol or formic acid is still hindered by various difficulties including the low activity and selectivity of the catalysts, the water management, and fuel crossover. ${ }^{2,10}$ This later is mainly due to the permeability of the Nafion membrane to the fuel. ${ }^{7,11-17}$ To overcome this difficulty and, in fact, to avoid completely the use of a polymer membrane, microfluidic fuel cells have been developed. ${ }^{18-20}$ The working principle of these systems is the following: Two flow streams, containing diluted $\mathrm{H}_{2} \mathrm{SO}_{4}$ or $\mathrm{KOH}$, can carry separately the fuel and the oxidant without being mixed, leading to a well-defined liquid-liquid interface. This is possible when the flow channel has micrometric dimension, thus the number of Reynolds is low. ${ }^{20}$ Furthermore, the oxygen can be taken directly from the air through a porous gas diffusion layer (GDL) such as carbon paper. ${ }^{21}$ These microfluidic fuel cells are also called membraneless micro fuel cells or laminar flow fuel cells (LFFC). ${ }^{21}$ Substituting the polymer membrane by a microfluidic electrolyte can dramatically reduce the cost of the fuel cell, and also avoid several commonly encountered challenges in the polymer electrolyte fuel cells, namely, membrane humidification control and water management. ${ }^{22}$ Moreover, disadvantages such as swelling, shrinkage and degradation of the polymer membrane are not found when using the liquid-liquid interface (virtual membrane) between two laminar streams. ${ }^{19}$ Additionally, the use of a flowing electrolyte also allows removing poisonous carbonates when using alkaline solutions. $^{23}$

While most attention has been given to increase the maximum power density of microfluidic fuel cells, other important aspects such as cycling stability, orientation ${ }^{24}$ and bubble effect ${ }^{25,26}$ have only been partially addressed. In order to study experimentally these issues, the stability of the electrodes should be assured. In particular, the cathode has to be stable since the electrochemical oxidation of carbon substrate and the oxygen reduction reaction (ORR) take place

*Electrochemical Society Active Member.

${ }^{\text {a }}$ Present address: Institute of Technical Thermodynamics/Electrochemical Energy

Technology, German Aerospace Center (DLR), 70569 Stuttgart, Germany.

${ }^{\mathrm{z} E}$-mail: nicolas.alonso.vante@univ-poitiers.fr simultaneously: ${ }^{27}$

$$
\begin{array}{cr}
\mathrm{C}+2 \mathrm{H}_{2} \mathrm{O} \rightarrow \mathrm{CO}_{2}+4 \mathrm{H}^{+}+4 \mathrm{e}^{-} & \mathrm{E}^{\circ}=0.207 \mathrm{~V} / \mathrm{SHE} \\
1 / 2 \mathrm{O}_{2}+2 \mathrm{H}^{+}+2 \mathrm{e}^{-} \rightarrow \mathrm{H}_{2} \mathrm{O} & \mathrm{E}^{\circ}=1.229 \mathrm{~V} / \mathrm{SHE}
\end{array}
$$

Platinum nanoparticles supported onto carbon black, namely Vulcan $\mathrm{XC}-72$, are still widely used as cathode catalyst. The carbon support has high surface area and good electronic conductivity. However, it is not stable at high potentials and its oxidation leads to the agglomeration of the nanoparticles associated with nanoparticles detachment and loss of electrical contact. ${ }^{28,29}$ Consequently, the electrochemical active surface area (ESA) of the nanoparticles is reduced and a significant loss in performance is produced. ${ }^{30,31}$ Intensive research is currently conducted for developing more efficient catalyst supports. ${ }^{32}$ The most suitable support is expected to have a good electronic conductivity and high electrochemical stability. Multi-walled carbon nanotubes (MWCNT) combined with surface defects, meet the aforementioned requirements. This support has a wide electrochemical potential window, good mechanical stability and large surface area. ${ }^{29,33}$ Additionally, improvement in the catalytic performance and electrochemical stability of carbon nanotubes (CNT) as supports has been reported..$^{29,34-36}$ It has been shown that this substrate enhances the electron charge transfer characteristics ${ }^{37-39}$ and CO tolerance, ${ }^{40}$ due to a strong interaction existing between Pt nanoparticles and graphitic domains of carbon. ${ }^{40,41}$ This strong nanoparticles-support interaction is an important ingredient leading to an enhanced stability.

In this work, $\mathrm{Pt} / \mathrm{MWCNT}$ catalyst was synthesized via the carbonyl chemical route, which is physically and electrochemically characterized. Electrochemical stability in both half-cell and fuel cell system was evaluated. Phenomena such as the orientation, bubble effect and fuel crossover in a formic acid microfluidic fuel cell were studied in details for a better understanding the fuel cell system, operating in the real applied conditions.

\section{Experimental}

Synthesis of Pt supported onto MWCNT and C catalysts.- Ptcarbonyl complex was synthesized according to the chemical procedure reported elsewhere. ${ }^{40,42}$ Methanol was used as a solvent for the reaction of $\mathrm{Pt}$ under $\mathrm{CO}$ atmosphere. The synthesis was carried out at $50-55^{\circ} \mathrm{C}$ for $24 \mathrm{~h}$, under constant stirring, until the color of the solution turned to black green. The molar ratio between sodium and hexachloroplatinic ions was fixed to 6. Once the Pt-carbonyl complex was synthesized, multi-walled carbon nanotubes (MWCNT $95 \mathrm{wt} \%$, Sigma-Aldrich) were added to the carbonyl complex solution in order to obtain the catalyst with $20 \mathrm{wt} \%$ loading onto the substrate. The impregnation process was conducted by stirring the mixture under the inert gas atmosphere for $12 \mathrm{~h}$. The powder was recovered after 
the evaporation of the solvent, and then rinsed with Milli-Q water $(18.2 \mathrm{M} \Omega \mathrm{cm})$ to eliminate the impurities. The powder was obtained by filtration, and then dried over night. For comparison study, $\mathrm{Pt} / \mathrm{C}$ catalyst was synthesized following the same procedure. Carbon Vulcan XC-72 (previously treated at $400^{\circ} \mathrm{C}$ for $4 \mathrm{~h}$ under $\mathrm{N}_{2}$ ) was used to replace MWCNT.

Physical characterization.- The X-ray diffraction (XRD) analysis of the powders was performed with a Bruker D5005 diffractometer operating under $40 \mathrm{kV}$ and $40 \mathrm{~mA} \mathrm{Cu}-\mathrm{K}_{\alpha}(\lambda=1.5418 \AA)$ radiation, in the angular range of $20-90^{\circ}(2 \theta)$ with a $0.05^{\circ}(2 \theta)$ step. The diffraction patterns were analyzed using a computer refinement program (Fityk software).

We used a Horiba Jobin Yvon Labram HR800UV Raman spectrometer using an $\mathrm{Ar}^{+}$(MellesGriot) laser as light source equipped with a CCD cooled detector. The Raman instrument was coupled to an Olympus microscope with analyzed region of 100x microscope objective. The frequency and power of the laser were $514.5 \mathrm{~nm}$ and $0.04 \mathrm{~mW}$, respectively. The spectra were recorded at a resolution of $1 \mathrm{~cm}^{-1}$.

Thermal gravimetric analysis/differential thermal analysis (TGDTA) measurements were carried out on a SDT Q600 thermal analyzer in air condition at a scan rate of $5^{\circ} \mathrm{C} \mathrm{min}{ }^{-1}$ in the range from room temperature to $800^{\circ} \mathrm{C}$ to obtain information on the decomposition and combustion properties of catalysts.

The Pt/MWCNT and Pt/C catalysts were analyzed with a JEOL JEM-2100 transmission electron microscopy (TEM) operating at $200 \mathrm{kV}$ acceleration voltages.

Electrochemical characterization.-Electrocatalytic inks of $\mathrm{Pt} / \mathrm{MWCNT}$ and $\mathrm{Pt} / \mathrm{C}$ were prepared as follows: $10 \mathrm{mg}$ catalysts, 250 $\mu \mathrm{L}$ Nafion solution (5 wt $\%$ in water/aliphatic alcohol solution, SigmaAldrich) and $1250 \mu \mathrm{L}$ Milli-Q water $(18.2 \mathrm{M} \Omega \mathrm{cm})$ were mixed and sonicated for $1 \mathrm{~h}$. Thereafter, $3 \mu \mathrm{L}$ of the mixture were taken out and dropped on a glassy carbon electrode. Then it was dried under $\mathrm{N}_{2}$ flow at room temperature for $30 \mathrm{~min}$.

The electrochemical measurements were carried out using an Autolab PGSTAT potentiostat 30 and a three-electrode cell. The electrolyte was prepared from $\mathrm{H}_{2} \mathrm{SO}_{4}$ (99.6\% Suprapur, Merck) and Milli$\mathrm{Q}$ water $(18.2 \mathrm{M} \Omega \mathrm{cm})$. A plate of glassy carbon and a reversible hydrogen electrode (RHE) with a Luggin capillary were used as counter and reference electrode, respectively. A rotating disk electrode (RDE) served as working electrode. The catalysts were evaluated at $25^{\circ} \mathrm{C}$ with cyclic voltammetry (CV) and low sweep voltammetry (LSV) techniques, in $\mathrm{N}_{2}$ - and $\mathrm{O}_{2}$-saturated $0.5 \mathrm{M} \mathrm{H}_{2} \mathrm{SO}_{4}$, respectively. The $\mathrm{CV}$ was carried out from 0.05 to $1.2 \mathrm{~V} / \mathrm{RHE}$ at a scan rate of $50 \mathrm{mV} \mathrm{s}^{-1}$. The oxygen reduction reaction (ORR) measurements were performed with a rotation speed of $900 \mathrm{rpm}$ and a sweep rate $5 \mathrm{mV} \mathrm{s}^{-1}$.

Fuel cell measurements. - Two squared plates, two electrodes and two pieces of a multichannel structure comprise the microfluidic fuel cell. A scheme of the fuel cell is shown in Figure 1. The multichannel structure is made of a SU-8 photoresist polymer. It has an array of 10 micro-channels of $250 \mu \mathrm{m}$ high, $750 \mu \mathrm{m}$ wide, and $20 \mathrm{~mm}$ long arranged in parallel. The plates were made in polyether-etherketone (PEEK). The dimensions of the plates are $25 \mathrm{~mm}$ long, $25 \mathrm{~mm}$ wide and $6 \mathrm{~mm}$ high. The electrodes were "sandwiched" between the plates connecting two current collectors made of copper. Two structures of SU-8 with the microchannels were placed between the electrodes. A nanoporous polycarbonate filter Cyclopore $(0.1 \mu \mathrm{m}$ pore size) served to avoid the initial mixing of the streams and to minimize fuel crossover. ${ }^{43}$

The electrodes of the microfluidic fuel cell were elaborated as follows. Two inks containing the required amounts of catalyst, $200 \mu \mathrm{L}$ Nafion solution, $300 \mu \mathrm{L}$ Milli-Q water $(18.2 \mathrm{M} \Omega \mathrm{cm})$ and $2500 \mu \mathrm{L}$ isopropanol (extra pure, Acros Organics) were prepared. After $1 \mathrm{~h}$ of sonication, the ink was sprayed on a gas diffusion layer (GDL) support (Ballard AvCarb P75T). This porous GDL allows the cathode to take the oxidant in gaseous phase. $\mathrm{O}_{2}$ was introduced as oxidant at the cathode side. The GDL was weighed before and after deposition of the catalysts to determine the metal loading of $1 \mathrm{mg} \mathrm{cm}^{-2}$ for cathode and $5 \mathrm{mg} \mathrm{cm}^{-2}$ for anode. The anode and the cathode were made from Pd-black ( $<25 \mathrm{~nm}$, Sigma-Aldrich) and Pt/MWCNT catalysts, respectively. For the electrochemical stability test in a fuel cell system, another cathode, $20 \mathrm{wt} \% \mathrm{Pt} / \mathrm{C}$ catalyst, was prepared in a similar way.

Current-potential curves (I-E) were registered by measuring the current and cell potential when applying an electronic load from a Source meter (Keithley 2611A). This device was controlled with an in-house LabVIEW program. The measurements were carried out in galvanostatic mode and the values were recorded every $1 \mathrm{~s}$. The current densities and power densities corresponding to microfluidic fuel cell experiments were normalized by the geometric area of the electrode $\left(1 \mathrm{~cm}^{2}\right)$. The fuel and the electrolyte streams pass over the anode and cathode respectively using a minipuls-3 peristaltic pump (Gilson), and leave the microchannel through the outlet, that are plugged into the

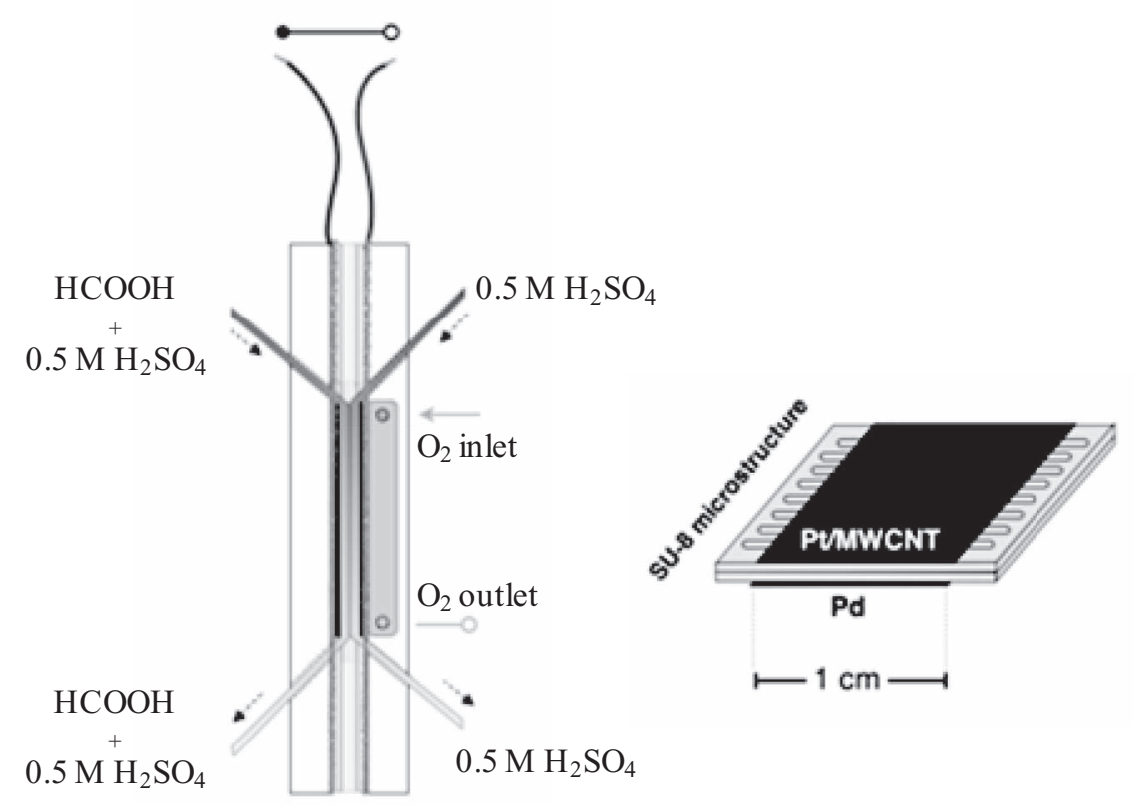

Figure 1. Scheme of the microfluidic fuel cell, with Pt/MWCNT cathode, Pd-black anode, and two SU-8 multichannel structures. 

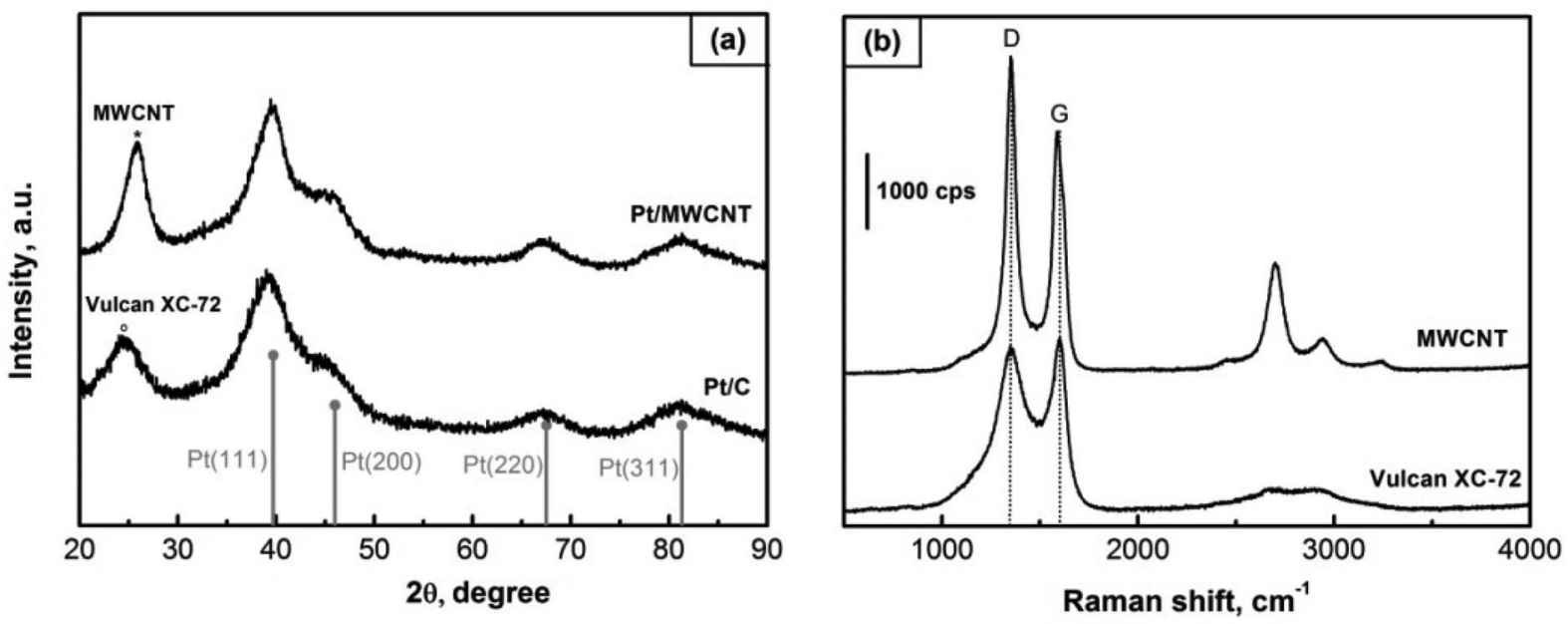

Figure 2. (a) X-ray diffraction patterns (XRD) of Pt/MWCNT and Pt/C catalysts, as-prepared. (b) The Raman spectra (RS) of the carbon supports.

reservoirs. A reversible hydrogen electrode (RHE) with a Luggin capillary is placed into the reservoir to enable recording of the performance of the cathode and anode independently. ${ }^{21}$ In this work, the cell potential as well as the cathode potential was measured at each cell current. The anode potential was deduced: $\mathrm{E}_{\mathrm{ano}}=\mathrm{E}_{\mathrm{cat}}-\mathrm{E}_{\mathrm{cell}}$. The reservoirs of the fuel and the electrolyte had a volume of $20 \mathrm{~mL}$ and the streams were recycled. The anode stream (anolyte) and the cathode stream (catholyte) contained $0.5 \mathrm{M} \mathrm{H}_{2} \mathrm{SO}_{4}$, as electrolyte. Only the anolyte carried the fuel: $\mathrm{HCOOH}$ (Sigma-Aldrich) with concentrations of $1 \mathrm{M}, 5 \mathrm{M}$ and $10 \mathrm{M} . \mathrm{O}_{2}$ was introduced into the cathode side as oxidant. For all the tests a constant flow rate of $3.4 \mathrm{~mL} \mathrm{~min}{ }^{-1}$ was chosen with the optimized flow rate (data not shown).

\section{Results and Discussion}

Physical properties. - The XRD patterns of Pt/MWCNT and Pt/C powders, as prepared, are shown in Figure $2 \mathrm{a}$. For each catalyst, the observed diffraction peaks correspond to the FCC crystallographic structure of Pt. The broad peaks centered at $24.3^{\circ}$ and $25.7^{\circ}$ in the XRD patterns of Pt/MWCNT and Pt/C correspond to the carbon substrates. The broadness of the diffraction peaks gives account of the crystallite size of Pt nanoparticles. The apparent mean crystallite size (D) can be calculated according to the Scherrer equation:

$$
D=\frac{K \lambda}{\beta \cos \theta}
$$

where $\mathrm{K}$ is the shape factor and corresponds to 0.89 for spherical crystallites, $\lambda$ the wavelength (1.5406 ̊), $\beta$ the full width at half maximum (FWHM) and $\theta$ the diffraction angle. The values of D were determined by taking the diffraction peak of Pt from the plane (111). The calculated values of the apparent mean crystallite size are 2.0 and $1.6 \mathrm{~nm}$ for Pt/MWCNT and Pt/C samples, respectively. The XRD result of Pd-black shows the typical FCC structure. It was observed from XRD pattern of the Pd-black, the 5 diffraction peaks at $40.21^{\circ}$, $46.77^{\circ}, 68.30^{\circ}, 82.34^{\circ}$ and $86.87^{\circ}$ can be indexed to $\operatorname{Pd}(111), \operatorname{Pd}(200)$, $\mathrm{Pd}(220), \operatorname{Pd}(311)$ and $\mathrm{Pd}(222)$ planes, respectively (JCPDS, 87-0639). Using the (111) plane, the calculated Pd-black mean crystallite size is ca. $10 \mathrm{~nm}$ catalyst.

Raman spectroscopy was used to further characterize the carbon support. The spectra of MWCNT and carbon Vulcan XC-72 are shown in Figure $2 b$. The well-known $\mathrm{D}$ and $\mathrm{G}$ bands of carbon are located at $1350 \mathrm{~cm}^{-1}$ and $1585 \mathrm{~cm}^{-1}$, respectively. The $\mathrm{G}$ band is of particular interest since it provides information on the in-plane vibration of $\mathrm{sp}^{2}$-bonded carbon atoms. ${ }^{44}$ The presence of the D-band results from the breakdown of symmetry for carbon atoms located close to the edge of graphite sheets. ${ }^{45}$ The integrated intensity ratio $\left(\mathrm{I}_{\mathrm{D}} / \mathrm{I}_{\mathrm{G}}\right)$ allows estimating the degree of graphitization (hybridization) of a carbonaceous material. The $\mathrm{I}_{\mathrm{D}} / \mathrm{I}_{\mathrm{G}}$ ratio is 2.1 for Vulcan XC-72 and 1.7 for MWCNT. Therefore, carbon Vulcan XC-72 is less graphitized than MWCNT. The higher graphitization degree of carbon atoms of the substrates greatly affects the electrochemical stability of the supporting material; we noted that the substrate used for electrochemical stability discussed in the following sections shows a better stability with Pt/MWCNT.

TG-DTA thermal analysis done in air for Pt/carbon is shown in Figure 3. Firstly, the TGA curves see Figure 3a, show that the domi-
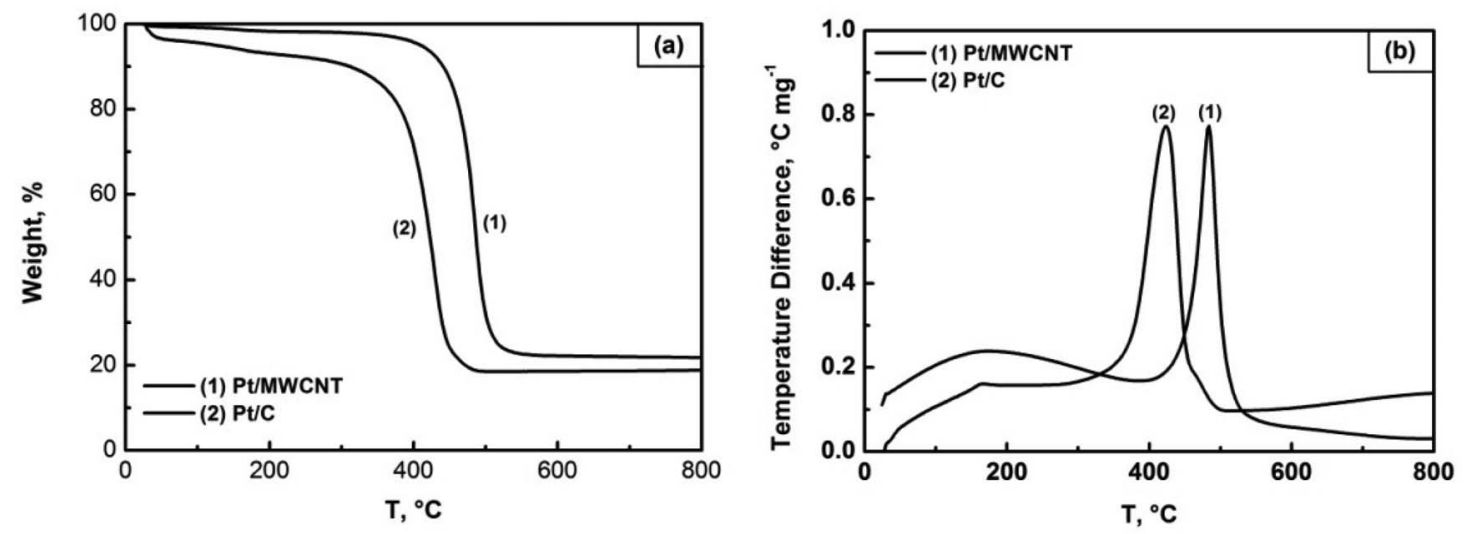

Figure 3. (a) Thermogravimetric, (b) Differential thermal analysis (TG-DTA) curves of Pt/MWCNT and Pt/C catalysts. The measurements were carried out in air atmosphere. 

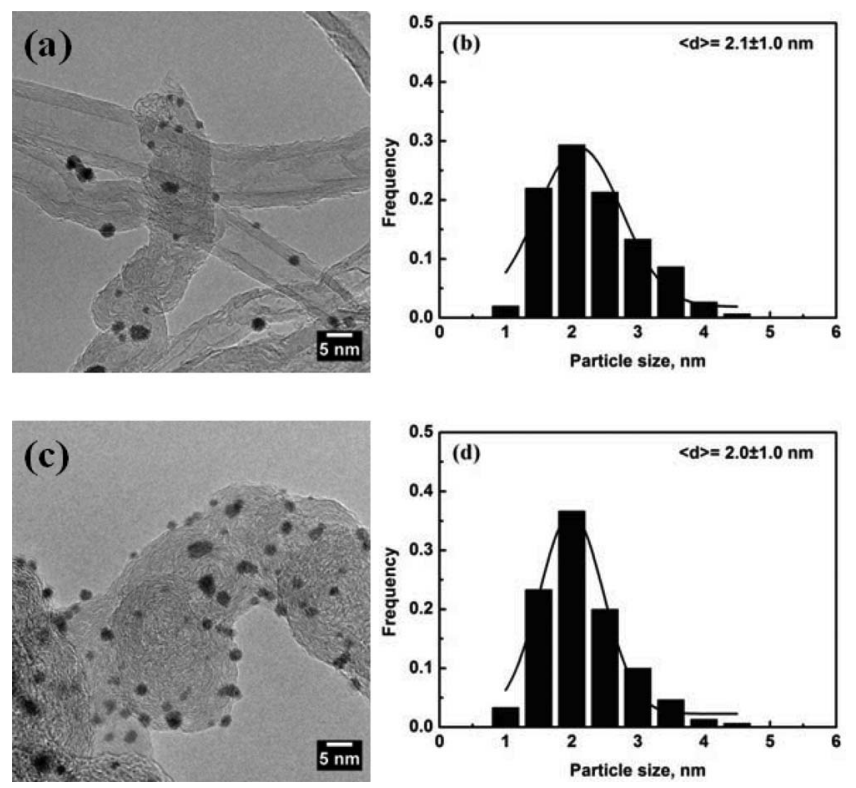

Figure 4. Transmission electron microscopy (TEM) images of (a) $\mathrm{Pt} / \mathrm{MWCNT}$ and (c) Pt/C catalysts, as-prepared. The corresponding size distribution histograms are shown in (b) and (d), respectively.

nant weight loss occurs from $400^{\circ} \mathrm{C}$ to $600^{\circ} \mathrm{C}$. This is clearly related to the combustion of carbon. It was confirmed that Pt loading was around $20 \mathrm{wt} \%$ for both Pt supported onto MWCNT and Vulcan XC-72 catalysts. Additionally, the carbon decomposition temperature of $\mathrm{Pt} / \mathrm{C}$ catalyst is of $423^{\circ} \mathrm{C}$ and increases up to $490^{\circ} \mathrm{C}$ for Pt/MWCNT catalyst, as shown in Figure $3 \mathrm{~b}$. This increase of the decomposition temperature is in fair agreement with the described Raman experiments above. It is in fact well-known that the decomposition temperature of a carbon substrate increases with its degree of graphitization.

TEM micrographs of Pt/MWCNT and Pt/C catalysts are shown in Figures $4 \mathrm{a}$ and $4 \mathrm{c}$. The corresponding histograms of the distribution of particle size are presented in Figures $4 \mathrm{~b}$ and $4 \mathrm{~d}$. These plots depict the diameter $<\mathrm{d}>$ of 200 particles. From the TEM micrographs we observe that the Pt nanoparticles are highly dispersed on the substrates. Additionally, the size distribution is rather homogenous. A mean particle size of $2.1 \pm 1.0 \mathrm{~nm}$ was obtained for the Pt/MWCNT, while for $\mathrm{Pt} / \mathrm{C}$ the average particle size was $2.0 \pm 1.0 \mathrm{~nm}$.

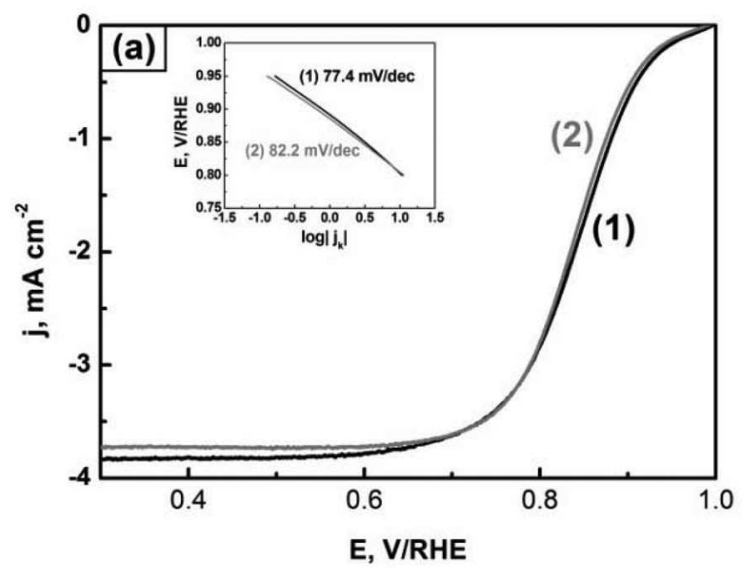

Table I. Half-wave potential $\left(\mathrm{E}_{1 / 2}\right)$, Tafel slopes and electrochemical active surface (ESA) calculated from the oxygen reduction reaction (ORR) and cyclic voltammetry measurements on Pt/MWCNT and Pt/C catalysts synthesized via carbonyl method.

\begin{tabular}{lcccc} 
& $\begin{array}{c}\mathrm{E}_{1 / 2} \\
(\mathrm{~V} / \mathrm{RHE})\end{array}$ & $\begin{array}{c}\text { Tafel slope } \\
\left(\mathrm{mV} \mathrm{dec}^{-1}\right)\end{array}$ & $\begin{array}{c}\mathrm{ESA}\left(\mathrm{cm}^{2}\right) \\
\text { Initial }\end{array}$ & $\begin{array}{c}\mathrm{ESA}\left(\mathrm{cm}^{2}\right) \\
3000 \mathrm{cycles}\end{array}$ \\
\hline $\mathrm{Pt} / \mathrm{MWCNT}$ & 0.85 & 77.4 & 1.6 & 0.57 \\
$\mathrm{Pt} / \mathrm{C}$ & 0.84 & 82.2 & 1.4 & 0.35
\end{tabular}

Electrochemical activity and stability. - The catalytic activity of the different catalysts toward the ORR was investigated by linear sweep voltammetry (LSV), at a rotation speed of $900 \mathrm{rpm}$. The ORR polarization curves, shown in the Figure 5a, reveal that the half-wave potential $\left(\mathrm{E}_{1 / 2}\right)$ is very close for both $\mathrm{Pt} / \mathrm{MWCNT}$ and $\mathrm{Pt} / \mathrm{C}$ electrocatalysts. From the ORR curve, it is possible to extract the Tafel slope that represents the electrochemical activity of the catalyst, as shown in the inset of Figure 5a. The obtained values are summarized in Table I. Similar Tafel slopes were obtained for both catalysts, namely $77.4 \mathrm{mV} \mathrm{dec}^{-1}$ for Pt/MWCNT, and $82.2 \mathrm{mV} \mathrm{dec}^{-1}$ for Pt/C. These results give account on similar ORR kinetics. The experimental slopes differ from the theoretical value of $120 \mathrm{mV} \mathrm{dec}{ }^{-1} .{ }^{46}$ Consequently, the adsorption isotherms of oxygenated species on Pt follow a Temkin isotherm.

The inset of Figure 5b shows the $\mathrm{H}_{\text {upd }}$ current-potential characteristics of Pt/MWCNT and Pt/C catalysts, after 20 voltammetric cycles (CV) from 0.05 to $1.2 \mathrm{~V} / \mathrm{RHE}$. They were carried out in $\mathrm{N}_{2}$-saturated $0.5 \mathrm{M} \mathrm{H}_{2} \mathrm{SO}_{4}$ electrolyte at a scan rate of $50 \mathrm{mV} \mathrm{s}^{-1}$. It is clear that the electrochemical response in the region of hydrogen adsorption/desorption is similar for both catalysts. In the so-called hydrogen region $(0.05<\mathrm{E}<0.4 \mathrm{~V} / \mathrm{RHE})$, the hydrogen is adsorbed solely on $\mathrm{Pt}$ sites. By calculating the charge associated with the $\mathrm{H}$ desorption, the electrochemical active surface area (ESA) of Pt was determined (see Table I). A correction of the double-layer current is applied and the ESA of polycrystalline Pt is obtained from:

$$
E S A=\frac{Q_{H}}{0.21}
$$

where $\mathrm{Q}_{\mathrm{H}}(\mathrm{mC})$ is the charge associated to the desorption of $\mathrm{H}$ in the hydrogen region $\left(\mathrm{H}_{\mathrm{upd}}\right)$ of the $\mathrm{CV}$ and $0.21 \mathrm{mC} \mathrm{cm}^{-2}$ is the charge associated to the desorption of a monolayer. ${ }^{47}$ The estimated ESA is very close for Pt on MWCNT and carbon Vulcan XC-72 substrates, with similar metal loading. The normalized electrochemical surface area (ESA) with respect to the number of cycles is shown in

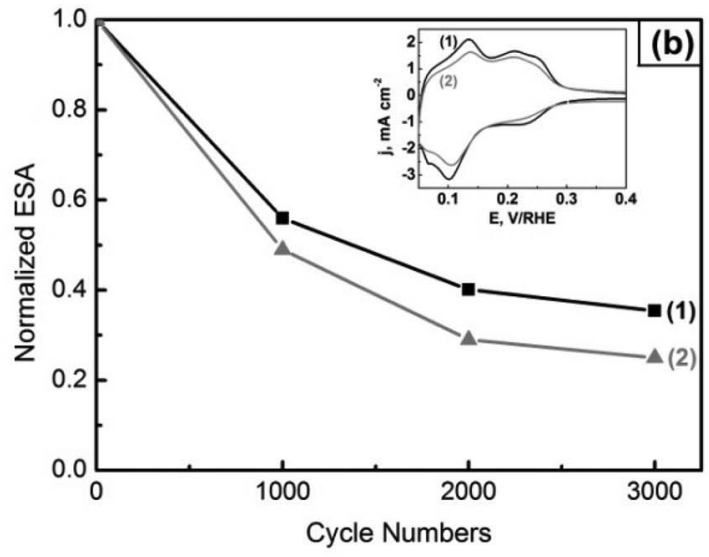

Figure 5. (a) ORR curves via LSV technique at a scan rate of $5 \mathrm{mV} \mathrm{s}^{-1}$ (the inset shows the Tafel curves); (b) Normalized ESA loss due to cycling from $0.05-1.2$ V/RHE in nitrogen-saturated $0.5 \mathrm{M} \mathrm{H}_{2} \mathrm{SO}_{4}$ at a scan rate of $50 \mathrm{mV} \mathrm{s}^{-1}$ (the inset shows the cyclic voltammograms) at $25^{\circ} \mathrm{C}$ for (1) Pt/MWCNT and (2) Pt/C as-prepared catalysts. 
Figure $5 \mathrm{~b}$. This latter is calculated using the following equation:

$$
E S A=\frac{E S A(N)}{E S A(0)} * 100
$$

where $\operatorname{ESA}(\mathrm{N})$ is the ESA calculated from Equation 5 and obtained at the $\mathrm{N}^{\text {th }}$ cycle. The ESA obtained at the initial cycle is $\operatorname{ESA}(0)$. As it is presented in Figure 5b, the normalized ESA of Pt/C decreases by $75 \%$ after 3000 voltammetric cycles, whereas for Pt/MWCNT this decrease corresponds to $65 \%$. An enhancement of stability under potential cycling is obtained with $\mathrm{Pt} / \mathrm{MWCNT}$ due to a higher graphitization degree of MWCNT substrate, leading to an increased strength of $\pi$-sites ( $\mathrm{sp}^{2}$-hybridized carbon) on the support that act as anchoring centers for platinum nanoparticles, thus strengthening the nanoparticles-support interaction. ${ }^{48,49}$ This strong interaction probably limits the agglomeration of platinum nanoparticles under potential cycling. Secondly, ESA decrease under potential cycling are based on the loss of electrochemically accessible Pt nanoparticles via carbon corrosion and detachment that is mainly a function of the carbon stability. ${ }^{29}$ It is indeed well known that highly ordered graphitic carbons such as MWCNT are less subsequent to corrosion phenomenon than disordered carbonaceous materials such as Vulcan XC-72.50 This result is in good agreement with the results from the fuel cell test.

Electrochemical characteristics of the Pd-black were evaluated (data not shown). The voltammetric profile in the $\mathrm{H}_{\text {upd }}$ region revealed that the $\mathrm{H}$-adsorption/desorption peak can be defined using this electrode. The formic acid oxidation was studied in a mixed electrolyte containing $0.5 \mathrm{M} \mathrm{H}_{2} \mathrm{SO}_{4}$ and $0.5 \mathrm{M} \mathrm{HCOOH}$ where Pd-black shows a high current density peaking at $0.62 \mathrm{~V} / \mathrm{RHE}$ in both scan directions revealing a high activity for the formic acid oxidation, with shoulder peaks at 0.42 and $0.8 \mathrm{~V} / \mathrm{RHE}$. Larsen et al.$^{51}$ demonstrated that there is no buildup of $\mathrm{CO}$ on the catalyst during formic acid electrooxidation on Pd-black, suggesting the direct oxidation path to $\mathrm{CO}_{2} .{ }^{52}$ This material was employed in a formic acid microfluidic fuel cell.
Fuel cell performance.-Stability tests. - To evaluate the stability of the Pt/MWCNT cathode in a microfluidic fuel cell system in comparison with $\mathrm{Pt} / \mathrm{C}$ cathode, cycling stability tests were performed using an optimized concentration (5 M HCOOH). The fuel concentration influence is shown in the following subsection. The j-E characteristics for the first 10-cycles are shown in Figure 6a. Similar maximum power densities were obtained : 23 and $22 \mathrm{~mW} \mathrm{~cm}^{-2}$, respectively, for $\mathrm{Pt} / \mathrm{MWCNT}$ and Pt/C in the fuel cell system. Subsequently, the load was fixed constant to $10 \mathrm{~mA}$ and $40 \mathrm{~mA}$ for $1000 \mathrm{~s}$ each. The power density and $E_{c a t}$ versus time curves are shown in Figures $6 b$ and $6 c$. We observed that generating $10 \mathrm{~mA}$, the cell performance remained stable with time for both cathodes. However, if the load is $40 \mathrm{~mA}$, then the power density dropped from $17 \mathrm{~mW} \mathrm{~cm}^{-2}$ to $3.5 \mathrm{~mW} \mathrm{~cm} \mathrm{~cm}^{-2}$ for Pt/C and from $16.5 \mathrm{~mW} \mathrm{~cm}^{-2}$ to $6.5 \mathrm{~mW} \mathrm{~cm}^{-2}$ for Pt/MWCNT. Thus the power density of the fuel cell with $\mathrm{Pt} / \mathrm{MWCNT}$ is around 2 times higher than that of Pt/C. In addition, $\mathrm{E}_{\text {cat }}$ of Pt/MWCNT depolarizes $67 \%$ less than $\mathrm{Pt} / \mathrm{C}$ when load increases from $10 \mathrm{~mA}$ to $40 \mathrm{~mA}$. The loss of the cathode performance is lower with Pt/MWCNT than with the $\mathrm{Pt} / \mathrm{C}$ allowing the fuel cell to generate more power. Thus, the stability and oxygen transport were improved using MWCNT as support. The use of MWCNT allows a quick replenishing of the depletion zone with $\mathrm{O}_{2}$ on Vulcan XC-72. The Pt/MWCNT is therefore a more suitable cathode for microfluidic fuel cells than $\mathrm{Pt} / \mathrm{C}$.

Fuel concentration.-The current-potential and power density characteristics of the microfluidic fuel cell with Pt/MWCNT cathode, using different concentrations of $\mathrm{HCOOH}$ in $0.5 \mathrm{M} \mathrm{H}_{2} \mathrm{SO}_{4}$ electrolyte are shown in Figure $7 \mathrm{a}$. We observed that with $1 \mathrm{M} \mathrm{HCOOH}$ there is no enough species to be oxidized on the Pd-black anode. As a result the open circuit potential (OCP) of the anode is high compared to $5 \mathrm{M}$ and $10 \mathrm{M} \mathrm{HCOOH}$. With $1 \mathrm{M} \mathrm{HCOOH}$ the maximum current density $\left(\mathrm{j}_{\max }\right)$ attained was $27 \mathrm{~mA} \mathrm{~cm}^{-2}$. The anode depolarized quickly due to the mass transport limitations resulting in a small power density of $5 \mathrm{~mW} \mathrm{~cm}{ }^{-2}$. With $5 \mathrm{M} \mathrm{HCOOH}$ the fuel cell delivered a maximum
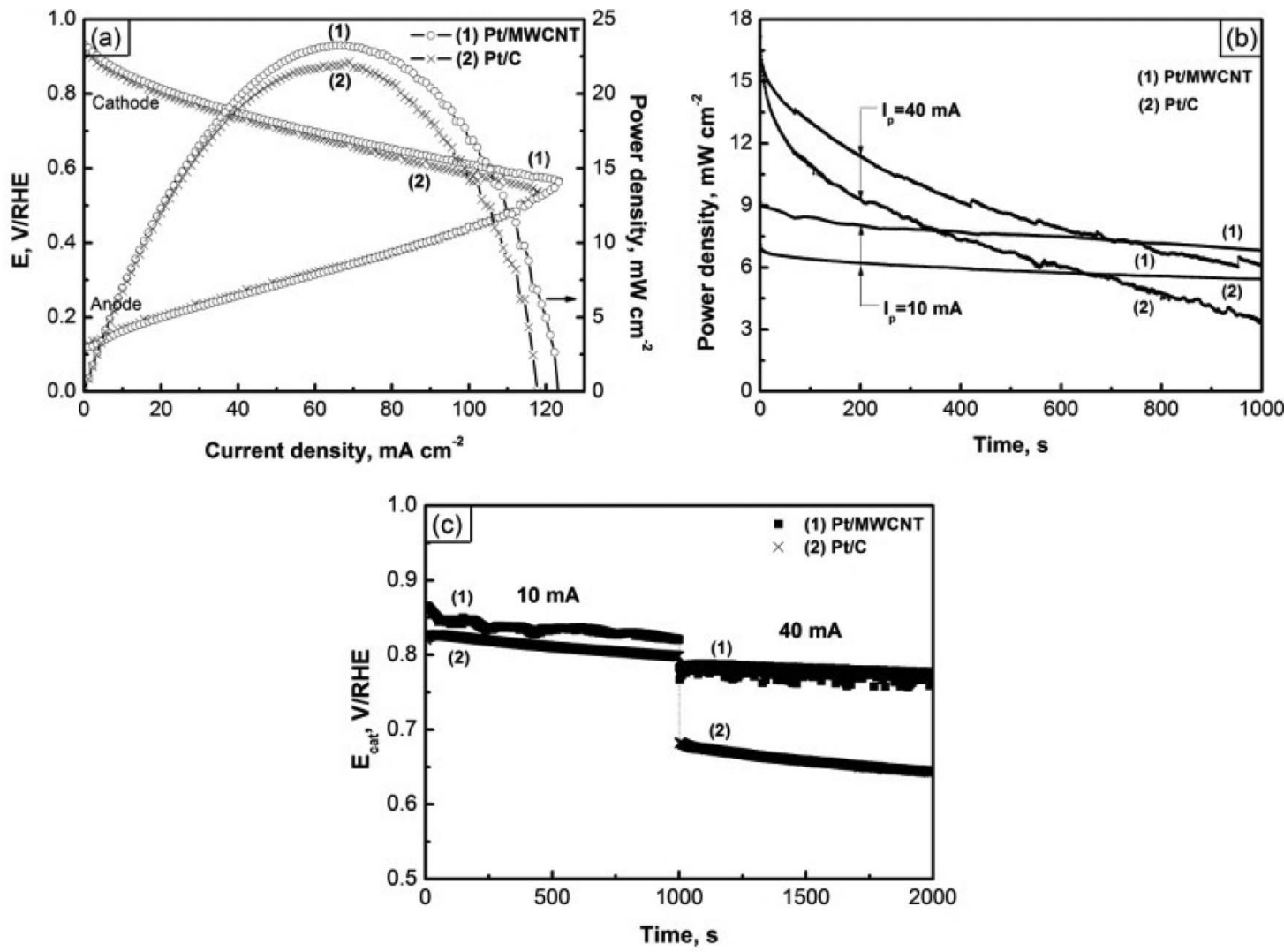

Figure 6. (a) First 10-cycles of current-potential and power density curves; (b) "discharging" power density and (c) cathode potential at fixed currents of $10 \mathrm{~mA}$ and $40 \mathrm{~mA}$ after 10-cycles for Pt/MWCNT and Pt/C cathodes versus Pd-black anode, respectively. 

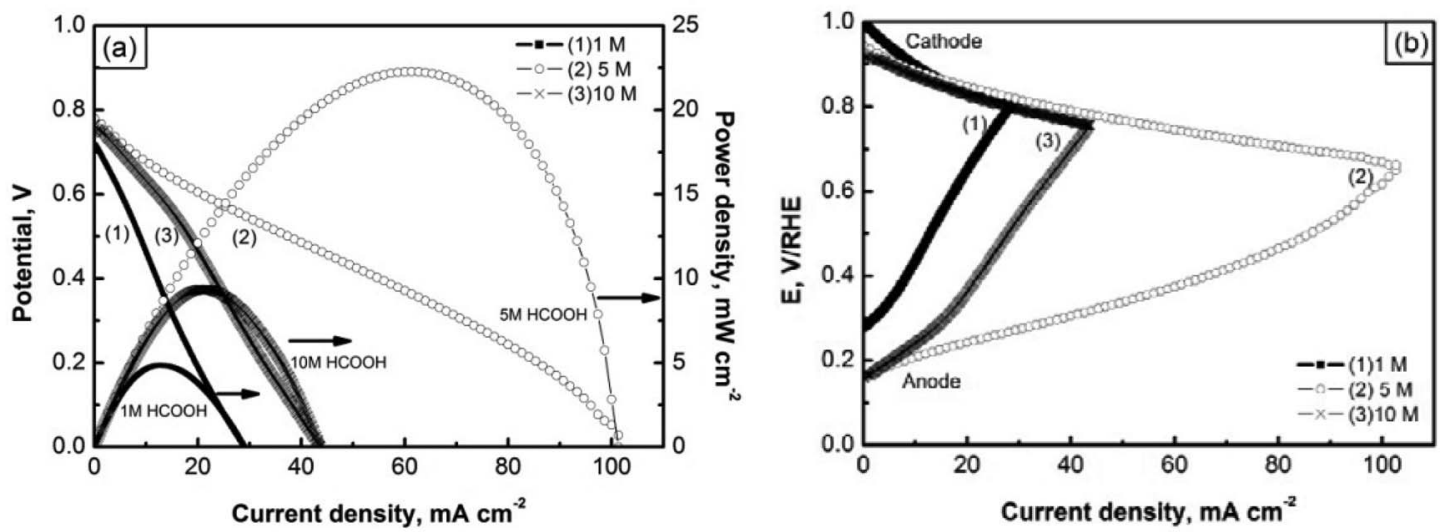

Figure 7. (a) Current-potential and power density curves of the fuel cell (b) anodic and cathodic potentials versus RHE with Pt/MWCNT cathode versus Pd-black anode with $\mathrm{HCOOH}(1 \mathrm{M}, 5 \mathrm{M}$, and $10 \mathrm{M})$, and $0.5 \mathrm{M} \mathrm{H}_{2} \mathrm{SO}_{4}$ was the base electrolyte.

current and power density of $102 \mathrm{~mA} \mathrm{~cm}^{-2}$ and $23 \mathrm{~mW} \mathrm{~cm}^{-2}$, respectively. Finally, at $10 \mathrm{M} \mathrm{HCOOH}$, the maximum current and power density dropped to $43 \mathrm{~mA} \mathrm{~cm}-2$ and $9.5 \mathrm{~mW} \mathrm{~cm}^{-2}$. This drop can be attributed to lowering of the conductivity of the anode stream at higher concentration of formic acid and some fuel crossover effect from the anode to the cathode stream, ${ }^{21}$ leading to the formation of a mixed-potential at the cathode.

Figure $7 \mathrm{~b}$ shows the individual cathodic and anodic performance for the experiment with different concentration of formic acid. It shows clearly that mass transport limitations at the anode and crossover issues at cathode depend on the fuel concentration. However, this relation is opposite for both phenomena. ${ }^{7,53}$ Increasing $\mathrm{HCOOH}$ will replenish the depletion zone of the anode more efficiently and the fuel utilization will be higher. ${ }^{21,54}$ Conversely, when using high concentrated formic acid more organic molecules diffuse from the anolyte to the catholyte producing a mixing zone. ${ }^{54,55}$ Furthermore, the conductivity of the electrolyte decreases with the $\mathrm{HCOOH}$ concentration and the internal resistance of the cell increases. ${ }^{53}$ Increasing the flow speed of the cathode stream $^{22}$ or using a nanoporous separator ${ }^{43}$ can diminish the rate of fuel crossover. The negative effect in microfluidic fuel cells can be also overcome by using tolerant and selective cathode catalysts. ${ }^{56,57}$ Finally, the optimal fuel concentration will also depend on the design characteristics of the fuel cell such as the length of the microchannel, the distance between the anode and the cathode, the type of GDL used, etc. ${ }^{58}$ From Figure $7 \mathrm{~b}$ we can observe that the anode current-potential curve is severely depolarized. The reason of this depolarization is related to the stability of the system and, more precisely, to the stability of the anode. The stability of the anode depends on the mass transport and $\mathrm{CO}_{2}$ generation. This later issue is discussed in the next subsection.

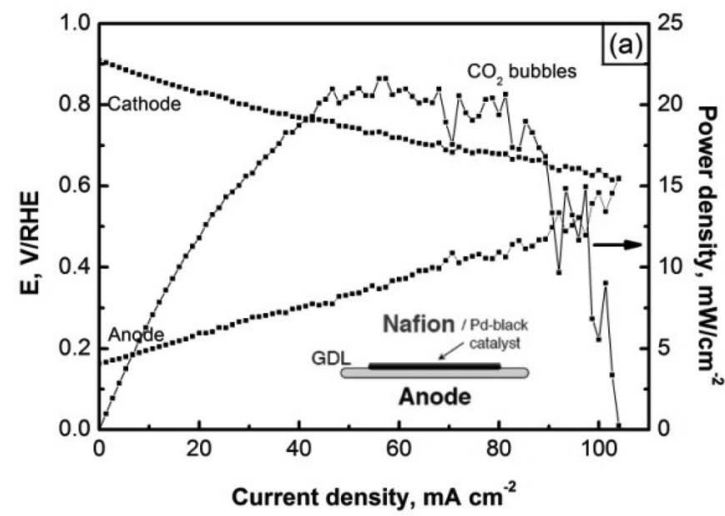

Bubble effect and orientation dependence.-According to Eq. 1, the oxidation of $\mathrm{HCOOH}$ on Pd-black nanoparticles of the anode produces $\mathrm{CO}_{2}$. When the fuel cell generates high electrical current, a large amount of $\mathrm{CO}_{2}$ bubbles comes out from the anode outlet. These bubbles can be observed with naked eye. This phenomenon in microfluidic fuel cells is known as the bubble-effect. ${ }^{25,26}$ We studied the bubble-effect using two different Pd-black anodes. Both had the same quantity of Pd nanoparticles but one of them had some drops of Nafion solution on top (ca. $10 \mu \mathrm{L}$ ). The j-E and power density curves of the fuel cell, having the anode with and without drops of Nafion are shown in Figures 8a and 8b, respectively. The formation of $\mathrm{CO}_{2}$ bubbles greatly perturbs the stability of the anode potential. Consequently, the performance of the fuel cell $\left(\mathrm{E}_{\text {cell }}\right)$ is also affected. The perturbation can be explained in terms of the shear velocity $(v)$ of a $\mathrm{CO}_{2}$ bubble. Such parameter can be calculated according to:

$$
v=\frac{V}{L H}
$$

where $V$ is the flow rate, $L$ the width and $H$ the height of the microchannels. Taking $V=3.4 \mathrm{~mL} \mathrm{~min}^{-1}, L=750 \mu \mathrm{m}$ and $\mathrm{H}=250 \mu \mathrm{m}$, a shear velocity $v=30 \mathrm{~cm} \mathrm{~s}^{-1}$ is obtained for the particular channel geometry used in this work. The distance between the beginning of the surface of the Pd-black anode and exit of the $\mathrm{CO}_{2}$ is about $1 \mathrm{~cm}$. Therefore, it can be estimated that a $\mathrm{CO}_{2}$ bubble would exit, by the shear force in $0.033 \mathrm{~s}$. This time is long enough to perturb the laminar flow at the depletion zone of the anode, causing turbulence and points of no contact at the liquid-solid interface. Indeed, the bubble generation in the microchannels alters the flow field completely and causes the increase of the mixing of the two inlet streams. ${ }^{26}$ The perturbation by the $\mathrm{CO}_{2}$ bubbles is reflected by the increasing

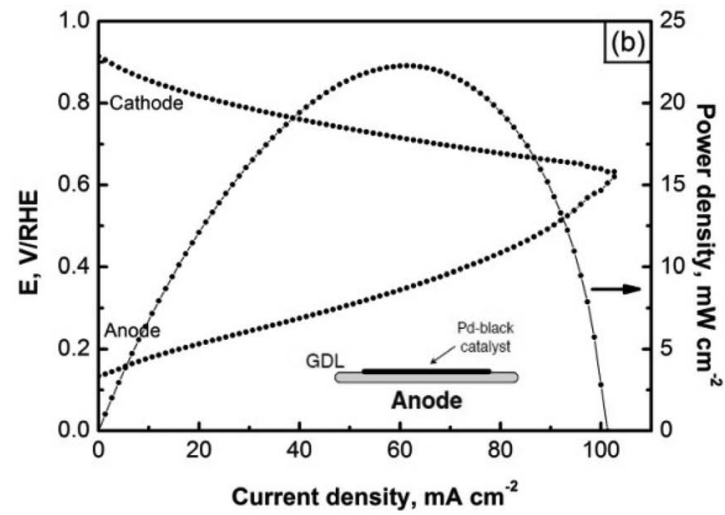

Figure 8. Current-potential and power density curves of the fuel cell with Pt/MWCNT cathode and Pd-black anode (a) with and (b) without drops of Nafion on top of the anode. 

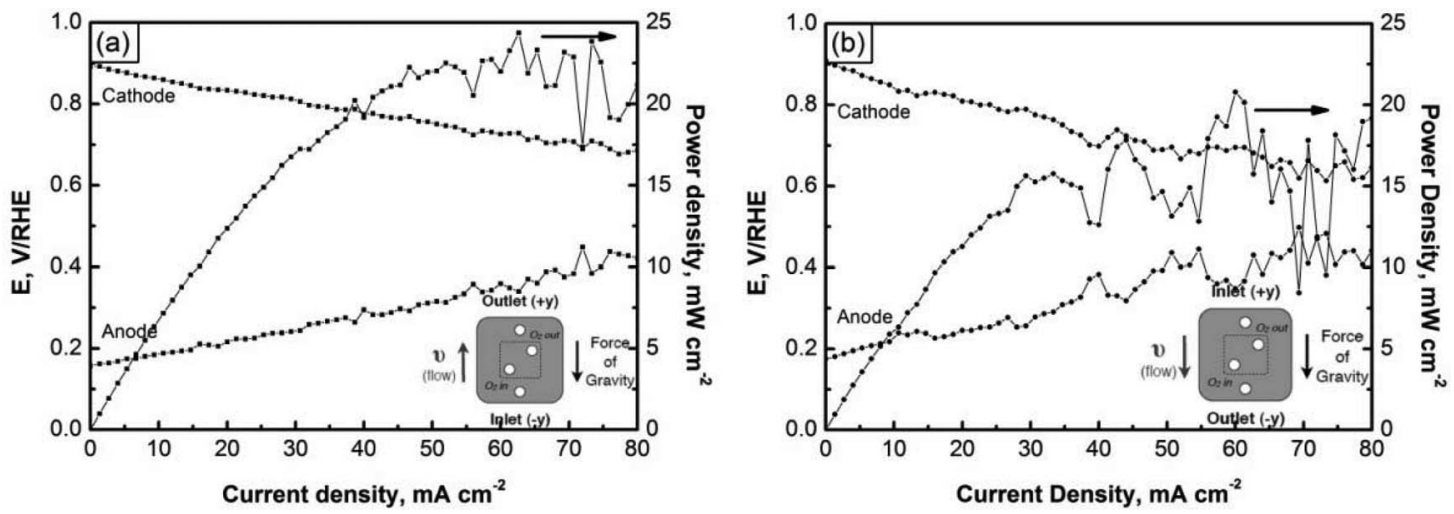

Figure 9. Orientation dependence: (a) inlet down $(-\mathrm{y})$, outlet up $(+\mathrm{y})$; (b) inlet up $(+\mathrm{y})$ and outlet down $(-\mathrm{y})$ of the fuel cell with Pt/MWCNT cathode and Pd-black anode. This latter had drops of Nafion on top of the anode.

noise of the $\mathrm{E}_{\text {cell }}$, particularly at $\mathrm{j}_{\max }$. As expected, the $\mathrm{CO}_{2}$ bubbles are favorably generated at high current densities. When the fuel cell is short-circuited the generated bubbles in the microfluidic system are easily trapped or accumulated in the microporous spaces of the anode. The bubble-effect becomes more obvious when using an anode with drops of Nafion on the surface, see Figure 8a. In this case, we observed that $\mathrm{CO}_{2}$ had even more difficulty to escape. Indeed, the excess of polymer blocks the porous sites inside the GDL of the anode. Nevertheless, the maximum power density of the fuel cell was similar with and without Nafion drops.

The performance of the fuel cell with two different orientations ( \pm y directions) had been investigated and the obtained results are presented in Figure 9. The force of gravity points out toward the $-y$ direction. Figure $9 \mathrm{a}$ presents the $\mathrm{j}-\mathrm{E}$ and power density characteristics when the liquid was introduced into the cell from $-\mathrm{y}$ to $+\mathrm{y}$ direction, i.e. from the bottom to the top of the fuel cell. Figure $9 \mathrm{~b}$ shows the situation when the liquid was introduced from $+y$ to $-\mathrm{y}$ direction, i.e. from the top to the bottom. In the first case ( $-\mathrm{y}$ direction), a power density of $23 \mathrm{~mW} \mathrm{~cm}^{-2}$ was achieved at $60 \mathrm{~mA} \mathrm{~cm}^{-2}$. In the second case $(+y$ direction) the power density decreased $2 \pm 2 \mathrm{~mW} \mathrm{~cm}$. This corresponds to a loss in performance of ca. $18 \%$. The hydrostatic pressure always pushes the $\mathrm{CO}_{2}$ bubbles upwards. The shear velocity, $v$, of a $\mathrm{CO}_{2}$ bubble decreases significantly by the double effect of the force of gravity and the external flow rate force. Consequently the bubble-effect is more notorious and it produces more noise at a cell voltage close to $j_{\max }$. The influence of the orientation of microfluidic fuel cell has been simulated by Xuan et al. ${ }^{24}$ and the results presented herein are in good agreement with such simulations.

Summing up, time-dependent experiments of microfluidic fuel cells are strongly affected by the mass transport and $\mathrm{CO}_{2}$ formation (bubbles) at the anode, orientation of the system and fuel crossover at the cathode. $\mathrm{A} \mathrm{CO}_{2}$-transpiring anode is required to avoid the loss in performance of the fuel cell with time. The stability of the cathode depends on the degree of poisoning by the fuel (fuel crossover). The overall performance depends on the carbon substrate that is used for supporting the catalytic nanoparticles.

\section{Conclusions}

Cathodes Pt/MWCNT and Pt/C catalysts, for a microfluidic fuel cell, that uses $\mathrm{HCOOH}$, were synthesized by the carbonyl chemical route. Additionally, the catalysts were physically and electrochemically characterized. The Pt nanoparticles had a mean particle size of ca. $2 \mathrm{~nm}$ and these were uniformly distributed on the respective substrates. The electrochemical characteristics were similar but $\mathrm{Pt} / \mathrm{MWCNT}$ showed a better electrochemical stability in both halfcell and fuel cell systems. The catalyst stability was correlated with the properties of carbon substrates. The performance in the microfluidic fuel cell with Pt/MWCNT cathode was studied by varying the fuel concentration and cell orientation. A maximum power density of $23 \mathrm{~mW} \mathrm{~cm}^{-2}$ was achieved when using $5 \mathrm{M} \mathrm{HCOOH}$. It was found that the loss in performance was mainly due to mass transport limitations and the low stability of the Pd-black anode. The bubbles of $\mathrm{CO}_{2}$ from the $\mathrm{HCOOH}$ greatly perturbed the stability of the anode potential. When the shear velocity of the flow was in the opposite direction to the gravity force, the $\mathrm{CO}_{2}$ bubbles perturbed less the current at the anode. With a constant load of $40 \mathrm{~mA}$, the fuel cell with Pt/MWCNT doubled the performance of the system provided with a Pt/C. Switching the load from $10 \mathrm{~mA}$ to $40 \mathrm{~mA}$, the Pt/MWCNT cathode potential depolarizes $67 \%$ less than the $\mathrm{Pt} / \mathrm{C}$. The stability of the catalyst and $\mathrm{O}_{2}$ transport was improved with MWCNT used as support.

\section{Acknowledgments}

J. Ma thanks "Ministère de l'Enseignement Supérieur et Recherche" for a fellowship and Poitou-Charentes region for financial support. A. S. Gago thanks University of Poitiers for financial support. The authors thank Dr. J. Santander, Dr. Juan Pablo Esquivel and Dr. N. Sabaté from the Instituto de Microelectronica de Barcelona for their kind support via the GICSERV program.

\section{References}

1. S. Sundarrajan, S. I. Allakhverdiev, and S. Ramakrishna, Int. J. Hydrogen Energy, 37, 8765 (2012)

2. S. K. Kamarudin, F. Achmad, and W. R. W. Daud, Int. J. Hydrogen Energy, 34, 6902 (2009).

3. Y. Zhu, S. Y. Ha, and R. I. Masel, J. Power Sources, 130, 8 (2004).

4. C. Rice, R. Ha, R. Masel, P. Waszczuk, A. Wieckowski, and T. Barnard, J. Power Sources, 111, 83 (2002).

5. C. M. Miesse, W. S. Jung, K. J. Jeong, J. K. Lee, J. Lee, J. Han, S. P. Yoon, S. W. Nam, T. H. Lim, and S. A. Hong, J. Power Sources, 162, 532 (2006).

6. X. Yu and P. G. Pickup, J. Power Sources, 182, 124 (2008).

7. K.-J. Jeong, C. M. Miesse, J.-H. Choi, J. Lee, J. Han, S. P. Yoon, S. W. Nam, T.-H. Lim, and T. G. Lee, J. Power Sources, 168, 119 (2007).

8. Y. Zhu, Y. Kang, Z. Zou, Q. Zhou, J. Zheng, B. Xia, and H. Yang, Electrochem Commun., 10, 802 (2008).

9. X.-M. Wang, J. Wang, Q.-Q. Zou, and Y.-Y. Xia, Electrochim. Acta, 56, 1646 (2011).

10. T. S. Zhao, W. W. Yang, R. Chen, and Q. X. Wu, J. Power Sources, 195, 3451 (2010).

11. A. Blum, T. Duvdevani, M. Philosoph, N. Rudoy, and E. Peled, J. Power Sources, 117, 22 (2003).

12. L. Li, J. Zhang, and Y. Wang, J. Membrane Sci., 226, 159 (2003).

13. Y. Zhang, W. Cai, F. Si, J. Ge, L. Liang, C. Liu, and W. Xing, Chem. Commun., 48 2870 (2012).

14. M. Ahmed and I. Dincer, Int. J. Energy Res., 35, 1213 (2011).

15. K. Ramya and K. S. Dhathathreyan, J. Electroanal. Chem., 542, 109 (2003).

16. C. Y. Du, T. S. Zhao, and W. W. Yang, Electrochim. Acta, 52, 5266 (2007).

17. C. Xu, A. Faghri, X. Li, and T. Ward, Int. J. Hydrogen Energy, 35, 1769 (2010).

18. R. Ferrigno, A. Stroock, T. Clark, M. Mayer, and G. Whitesides, J. Am. Chem. Soc, 124, 12930 (2002)

19. S. A. Mousavi Shaegh, N. T. Nguyen, and S. H. Chan, Int. J. Hydrogen Energy, 35, 5675 (2011).

20. E. Kjeang, N. Djilali, and D. Sinton, J. Power Sources, 186, 353 (2009). 
21. R. S. Jayashree, L. Gancs, E. R. Choban, A. Primak, D. Natarajan, L. J. Markoski, and P. J. A. Kenis, J. Am. Chem. Soc., 127, 16758 (2005).

22. R. S. Jayashree, S. K. Yoon, F. R. Brushett, P. O. Lopez-Montesinos, D. Natarajan, L. J. Markoski, and P. J. A. Kenis, J. Power Sources, 195, 3569 (2010).

23. M. S. Naughton, F. R. Brushett, and P. J. A. Kenis, J. Power Sources, 196, 1762 (2011).

24. J. Xuan, M. K. H. Leung, D. Y. C. Leung, and H. Wang, Appl. Energy, 90, 80 (2012).

25. J.-C. Shyu and C.-L. Huang, J. Power Sources, 196, 3233 (2011).

26. J.-C. Shyu, C.-S. Wei, C.-J. Lee, and C.-C. Wang, Appl. Therm. Eng., 30, 1863 (2010).

27. K. Kinoshita, Carbon : Electrochemical and Physicochemical Properties, Wiley, New York (1988).

28. R. Borup, J. Meyers, B. Pivovar, Y. S. Kim, R. Mukundan, N. Garland, D. Myers, M. Wilson, F. Garzon, D. Wood, P. Zelenay, K. More, K. Stroh, T. Zawodzinski, J. Boncella, J. E. McGrath, M. Inaba, K. Miyatake, M. Hori, K. Ota, Z. Ogumi, S. Miyata, A. Nishikata, Z. Siroma, Y. Uchimoto, K. Yasuda, K.-i. Kimijima, and N. Iwashita, Chem. Rev., 107, 3904 (2007).

29. F. Hasche, M. Oezaslan, and P. Strasser, Phys. Chem. Chem. Phys., 12, 15251 (2010)

30. X.-Z. Yuan, H. Li, S. Zhang, J. Martin, and H. Wang, J. Power Sources, 196, 9107 (2011).

31. Y. Yu, H. Li, H. Wang, X.-Z. Yuan, G. Wang, and M. Pan, J. Power Sources, 205, 10 (2012).

32. S. Sharma and B. G. Pollet, J. Power Sources, 208, 96 (2012).

33. W. Zhang, P. Sherrell, A. I. Minett, J. M. Razal, and J. Chen, Energy Environ. Sci., 3, 1286 (2010).

34. C.-L. Lee, Y.-C. Ju, P.-T. Chou, Y.-C. Huang, L.-C. Kuo, and J.-C. Oung, Electrochem. Commun., 7, 453 (2005).

35. L. Li and Y. Xing, J. Phys. Chem. C, 111, 2803 (2007).

36. X. Li and I. M. Hsing, Electrochim. Acta, 51, 5250 (2006).

37. G. G. Wildgoose, C. E. Banks, and R. G. Compton, Small, 2, 182 (2006).

38. C. E. Banks and R. G. Compton, Analyst, 131, 15 (2006).

39. C. E. Banks, T. J. Davies, G. G. Wildgoose, and R. G. Compton, Chem. Commun., 829 (2005)
40. J. Ma, A. Habrioux, N. Guignard, and N. Alonso-Vante, J. Phys. Chem. C, 116, 21788 (2012).

41. J. Oh, T. Kondo, D. Hatake, Y. Iwasaki, Y. Honma, Y. Suda, D. Sekiba, H. Kudo, and J. Nakamura, J. Phys. Chem. Lett., 1, 463 (2009).

42. E. Favry, D. Wang, D. Fantauzzi, J. Anton, D. S. Su, T. Jacob, and N. Alonso-Vante, Phys. Chem. Chem. Phys., 13, 9201 (2011).

43. A. S. Hollinger, R. J. Maloney, R. S. Jayashree, D. Natarajan, L. J. Markoski, and P. J. A. Kenis, J. Power Sources, 195, 3523 (2010).

44. T. Jawhari, A. Roid, and J. Casado, Carbon, 33, 1561 (1995).

45. L. E. McNeil, J. Steinbeck, L. Salamanca-Riba, and G. Dresselhaus, Carbon, 24, 73 (1986).

46. A. Damjanovic and V. Brusic, Electrochim. Acta, 12, 615 (1967).

47. T. J. Schmidt, H. A. Gasteiger, G. D. Stäb, P. M. Urban, D. M. Kolb, and R. J. Behm, J. Electrochem. Soc., 145, 2354 (1998).

48. T. Kondo, Y. Iwasaki, Y. Honma, Y. Takagi, S. Okada, and J. Nakamura, Phys. Rev. $B, \mathbf{8 0}, 233408$ (2009).

49. F. Coloma, A. Sepulveda-Escribano, J. L. G. Fierro, and F. Rodriguez-Reinoso, Langmuir, 10, 750 (1994).

50. H.-T. Fang, C.-G. Liu, C. Liu, F. Li, M. Liu, and H.-M. Cheng, Chem. Mater, 16, 5744 (2004)

51. R. Larsen, S. Ha, J. Zakzeski, and R. I. Masel, J. Power Sources, 157, 78 (2006).

52. M. Arenz, V. Stamenkovic, T. J. Schmidt, K. Wandelt, P. N. Ross, and N. M. Markovic, Phys. Chem. Chem. Phys., 5, 4242 (2003).

53. C. Rice, S. Ha, R. I. Masel, P. Waszczuk, A. Wieckowski, and T. Barnard, J. Power Sources, 111, 83 (2002).

54. A. Bazylak, D. Sinton, and N. Djilali, J. Power Sources, 143, 57 (2005).

55. I. B. Sprague, D. Byun, and P. Dutta, Electrochim. Acta, 55, 8579 (2010).

56. A. S. Gago, D. Morales-Acosta, L. G. Arriaga, and N. Alonso-Vante, J. Power Sources, 196, 1324 (2011).

57. A. S. Gago, Y. Gochi-Ponce, Y.-J. Feng, J. P. Esquivel, N. Sabaté, J. Santander, and N. Alonso-Vante, ChemSusChem, 5, 1488 (2012).

58. M. R. Thorson, F. R. Brushett, C. J. Timberg, and P. J. A. Kenis, J. Power Sources, 218, 28 (2012). 